\title{
Integration of Gender and Development Approach on Institutional Programs, Activities, and Projects of Higher Education Institution: An Input to Strategic Development Plan
}

\author{
Mary Ann S. Hernandez' ${ }^{1}$ Marcial M. Bandoy², Lerma P. Buenvinida ${ }^{3}$ \\ 1, 2, 3 Laguna State Polytechnic University, Philippines
}

\begin{abstract}
The purpose of this paper is to determine the GAD-aligned Programs, Projects, and Activities' gender-related mandated functions and integration. To obtain the necessary information on individuals in Higher Education Institutions based on specific traits and standards and clearly define the institution's long-term direction based on the institution's aims and objectives. Gender and Development focus on Gender Mainstreaming, which is a technique that incorporates both gender concerns and practices into the strategy, execution, supervision, and evaluation of guidelines, processes, plans, and activities at all levels, ensuring that both genders benefit equally. The study used a descriptive methodology to measure the extent to which genderrelated activities integrated into mainstreaming mandatory functions and perceptions on GAD-aligned PPAs. There is no significant link between mandated outcome based on HEI-moderated (LUC or SUC) Instruction, Research, Extension, and Resource Management and perceived level of integration on the gender-related functions of Gender and Development Programs, Activities, and Projects, and GAD-aligned PPAs in mainstreaming. The mainstream GAD-aligned PPAs at the university do not predict the integration of GADrelated functions. The SUC/LUC category did not affect the relationship between the GAD-aligned PPAs and the level of integration when it approached the identified indicators.
\end{abstract}

Keywords: Mainstreaming, Integration, Mandated Functions, Related Functions, Gender and Development

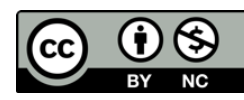

This is an open access article under the CC-BY-NC license.

\section{INTRODUCTION}

Gender and Development (GAD) is a development strategy that acknowledges women's and men's unequal status and circumstances in society. The execution of Republic Act 7192, popularly known as Women in Nation Building, was only "moderately known" among educational leaders. Insufficient training/seminars, a lack of financial assistance, a lack of priority for GAD programs, institutional collaboration on GAD-related activities, and implementation that is not sustainable were all recognized as concerns with GAD implementation by all HEIs. (Albaladejo, 2016).

The main concern was gender as a social relationship; the realm of symbolic analysis - the social construction of gender identity, according to Carol Miller, Shahra Razavi (1995): From WID to GAD: Conceptual Shifts in the Women and Development Discourse, UNRISD Occasional Paper No. 1, United Nations Research Institute for Social Development (UNRISD), This sociological background has tended to inform the gender methods that used women and development advocates and scholars in this article. They intended to establish the concrete materiality of gender subordination as the form adopted by a wide range of institutions policy and practices that involve the household, market, state, and community.

Women and Development (WAD) is a gender-based development concept that emerged in the 1970s regarding Southern academics and activists' Women in Development. WAD's main complaint was that women-specific measures did not get hold of the circumstances of women in developing countries, even though there is no visible difference between the two methods. According to their complaint (Rathgeber 1989), while women have always existed in development processes, they have always been included in an exploitative manner that perpetuates global imbalances. In the 1980s, Gender and Corresponding author lermabuenvinida@lspu.edu.phl DOI: https://doi.org/10.31098/ijmesh.v4i2.782 
International Journal of Management, Entrepreneurship, Social Science and Humanities (IJMESH), Vol. 4 (2), 182-192

Integration of Gender and Development Approach on Institutional Programs, Activities, and Projects of

Higher Education Institution: An Input to Strategic Development Plan

Mary Ann S. Hernandez; Marcial M. Bandoy; Lerma P. Buenvinida

Development became a prominent alternative tactic (GAD). It focused on the social construction of gender and how it influences the duties and obligations that men and women envision accomplishing. The progress on women was not "tacked on"; it was a holistic strategy. This strategy questioned and aimed to realign existing social, political, and economic structures and institutions, viewed women as a heterogeneous group rather than a homogeneous one, and settle down on government engagement. In this setting, women were supposed to obtain evaluation as active change-makers (Rathgeber, 1989). One of the most prime projects to arise from this school of thought was gender mainstreaming. Gender mainstreaming was formally attended by countries participating in an international forum when they signed the Beijing Platform for Action (BPFA) at the World Conference for Women in 1995 and the General Assembly's Economic and Social Council (ECOSOC) Conference in 1997. ECOSOC provides the most widely used definition as "a strategic approach to making women and men's concerns and experiences an integral dimension in policy design, implementation, monitoring and program evaluation in all political, economic and societal fields..." with "last g" in many conflicting definitions of "gender mainstreaming" ("ECOSOC session of 1997" 1997).

The relationship between patriarchy and capitalism is more significant to WAD than the relationship between women and development. Most of the thinking about WAD remains undocumented despite the ongoing and pressing nature of development work in which many WAD theorists engage. This theory attempts to assess women's issues through the lenses of neo-Marxism and dependency theory.

Gender stereotypes and their influence on women in the global south have been highlighted in development programs over the years. However, to reduce poverty and poor socioeconomic status, we are seeing a shift in how women are incorporated into development efforts. (1) the welfare approach; (2) women in development (WID); (3) women and development (WAD); (4) gender and development (GAD); (5) the effectiveness approach (EA); and (6) mainstream gender equality are the six theoretical approaches (MGE). Martinez wants to know what the effects and utility of each of the six development theories entail.

The Mainstreaming Gender Equality (MGE) approach, also known as gender mainstreaming, is the most contemporary development method intended only on women. Gender mainstreaming guarantees that all gender concerns in society, politics, and programs are being addressed and forecasted. It all began in Beijing, China, in 1995 during the 4th United Nations Conference on Women. 189 state leaders agreed at the meeting that women and men be included in every development effort if a nation's economic growth and development are to succeed and progress. Various aid organizations, such as CIDA, have abandoned the WID technique due to a poor perception among supporters that it was too feminist, increasing male animosity of such initiatives. As a result, organizations like CIDA must now include men and women in their annual development reports when providing education, health care, and employment for both sexes.

Finally, all six theoretical methods are discussed:

1) It's vital to remember that no method can be completely neutral in terms of how it affects men's and women's power dynamics.

2) Furthermore, gender inequality is inextricably tied to the power struggle that prevents women from being recognized as important actors and negotiators in development processes.

3) Finally, the requirement for genuine fieldwork must be included in development theories. When putting diverse development theories into practice, individuals' collective demands must be taken into account.

As a result, gender mainstreaming in higher education is crucial not just for individual development but also for national development in the higher education provides a critical hub for facilitating the skills, information, and expertise required for economic and social progress. Higher Education Institutions play an important role in the globalized information economy, professional education, 
International Journal of Management, Entrepreneurship, Social Science and Humanities (IJMESH), Vol. 4 (2), $182-192$

Integration of Gender and Development Approach on Institutional Programs, Activities, and Projects of

Higher Education Institution: An Input to Strategic Development Plan

Mary Ann S. Hernandez; Marcial M. Bandoy; Lerma P. Buenvinida

national wealth development, and scientific and technological innovation. HEIs are also a powerful conduit for promoting the essential value of family and preserving women's position as cultural and historical transmitters in the Philippines.

GAD introduced a new way of thinking on how women and men are socially constructed and how "those constructions are powerfully reinforced by the social behaviors that both define and define them." The gendered division of labor and gender as a power relationship within institutions are the primary concerns of GAD. As a result, two key frameworks are utilized in this strategy: "gender roles" and "social relations analysis." 'Gender roles' investigates the social construction of identities in the home, as well as the resource availability expectations that come with 'maleness and femaleness.' "Social relations analysis" proves the social dimensions of hierarchical power relations ingrained in social institutions, as well as their deciding influence on "the relative position of men and women in society." This relative status affects women.

The Gender and Development (GAD) Center was established as a result of Republic Act 7192 (An Act to Promote the Integration of Women as Full and Equal Partners of Men in Development and Nation Building, and for Other Purposes), as well as the Memorandum Circulars of the National Commission on the Role of Filipino Women (NCRFW), the National Economic Development Authority (NEDA), and the Department of Budget and Management (DBM).

Higher Education Institutions serve as a support structure for the efficient and effective mainstreaming of gender plans, programs, and activities in the areas of instruction, research, extension, and production in the Institute and the local community for the advancement of RA 7192 and CHED Memorandum Order No. 1 series of 2015 "Establishing the Policies and Guidelines of Gender and Development" (HEIs).

The Magna Carta of Women (MCW), also known as Republic Act No. 9710, was enacted in September 2009 and is a local translation of the CEDAW's provisions, particularly those defining gender discrimination, state obligation, substantive equality, and temporary special measures. It implements the spirit of the CEDAW with the BPFA comprises the major statutory guidelines that all Responsible Agencies are supposed to follow (PCW). The MCW Implementing Rules and Regulations (IRR) is a set of rules that govern how the MCW operates. The Commission on Higher Education (CHED) which was approved in March 2010 and the organization is responsible for overseeing higher education (1) develop and promote gender-sensitive curricula; (2) develop gender-fair instructional materials; (3) ensure that educational institutions implement a capacity-building program on gender, peace, and human rights education for their officials, faculty, and non-teaching staff and personnel; and (4) promote partnerships between and among education sector players: (5) Encourage the advertising industry and other similar institutions to provide free use space and installation of displays for schools, colleges, and universities for campaigns to end discrimination and violence against women; and (6) encourage the advertising industry and other similar institutions to provide free use space and installation of displays for school, colleges, and universities for campaigns to end discrimination and violence against women, and (7) Ensuring that educational institutions provide scholarship programs for underprivileged women and girls by implementing minimum standards for the higher education institutions programs (MCW IRR, Section 16 of Rule IV).

The purpose of these Guidelines is to foster and institutionalize gender equality, responsiveness, and sensitivity in all aspects of Philippine higher education. The Guidelines of Commission on Higher Education includes Central and Regional Officers, as well as all private and public higher education institutions, will be subject. In terms of scope, the Guidelines include enabling mechanisms that CHED and HEIs must establish, such as the GFPS GAD Focal Point System, as well as the integration of gender equality principles in higher education's three core functions: (1) curriculum development, (2) genderresponsive research programs, and (3) gender-responsive extension programs. 
International Journal of Management, Entrepreneurship, Social Science and Humanities (IJMESH), Vol. 4 (2), 182-192

Integration of Gender and Development Approach on Institutional Programs, Activities, and Projects of

Higher Education Institution: An Input to Strategic Development Plan

Mary Ann S. Hernandez; Marcial M. Bandoy; Lerma P. Buenvinida

\section{Objectives of the Study}

The purpose of this study is to determine the perceived level of mainstreaming and integration of the Gender and Development Approach in Higher Education Institutions in Laguna of GAD-aligned PPAs in mainstreaming mandated functions and the perceived level of integration of Gender-related functions to clearly define its long-term direction in the strategic development plan and integrate people's efforts towards a co-equal society.

\section{MATERIALS AND METHODS}

The study used a descriptive research methodology, which entails collecting, evaluating, and integrating quantitative data. Through analysis of data measuring the mainstreaming mandated functions and perception of the respondent's GAD-aligned PPAs on the extent level of integration in the gender-related functions in Gender and Development of Higher Education Institutions, the research design helped gather quantifiable information that can be used for statistical reference in the respondents. The researcher also used a descriptive method of research in conducting the study to determine the needed information.

The respondents are composed of Higher Education Institutions in Laguna. Simple random sampling is a probability sampling technique in which the researcher creates a sample involving individuals that represent all members of the population has a chance of being included in the sample. Researchers choose these individuals according to specific traits or qualities.

To obtain the necessary information for the study, the researcher utilized a survey questionnaire that went through a validation process to test the reliability of the study. Before conducting this study, the researcher prepared a request letter and personally acquired permission from the University President to smoothly gather the much-needed data and information to enable to send a google form due to the pandemic and to answer the survey questionnaire by their faculty. The researcher assured that all information gathered will be used strictly for research purposes and kept confidential.

The data gathered from a group of Higher Education Institutions were organized, categorized, tallied, and presented in tables, and appropriate statistical tools were applied. Frequency, percentage distribution, and mean to present the details about the respondents' profile and means and standard deviation for their response. Pearson correlation will be used to examine the significant relationship among variables through multiple linear regression analysis. Process macro to reveal the significant relationship between Perceived Level of Integration on Gender-related functions and Gender and

Development Programs, Activities and Projects, and GAD-aligned PPAs in mainstreaming mandated functions based on Instruction, Research, Extension, and Management of Resources as moderated by HEI (LUC or SUC).

The quantitative data will be analyzed using percentages and frequencies in describing the profile of the respondents as to age, sex, civil status, years in service, highest educational attainment, academic rank, and designation, while the mean, the standard deviation will be applied in determining the level of Mainstreaming Mandated Functions and perceived level of integration on Gender-Related Functions in Higher Education Institutions in Laguna. 
International Journal of Management, Entrepreneurship, Social Science and Humanities (IJMESH), Vol. 4 (2), 182-192

Integration of Gender and Development Approach on Institutional Programs, Activities, and Projects of

Higher Education Institution: An Input to Strategic Development Plan

Mary Ann S. Hernandez; Marcial M. Bandoy; Lerma P. Buenvinida

\section{RESULTS AND DISCUSSION}

This chapter presents the analysis and interpretation of the data obtained in the study.

Table 1. Demographic Profile of the Respondents

\begin{tabular}{|c|c|c|c|}
\hline & & Frequency & Percent \\
\hline \multirow[t]{2}{*}{ Sex } & Female & 81 & 53.64 \\
\hline & Male & 70 & 46.36 \\
\hline \multirow[t]{5}{*}{ Age Range } & 21 - 30 yrs. old & 33 & 21.85 \\
\hline & $31-40$ yrs. old & 41 & 27.15 \\
\hline & 41 - 50 yrs. old & 32 & 21.19 \\
\hline & $51-60$ yrs. old & 35 & 23.18 \\
\hline & 61 and above & 10 & 6.62 \\
\hline \multirow[t]{4}{*}{ Civil Status } & Single & 65 & 43.05 \\
\hline & Married & 72 & 47.68 \\
\hline & Separated & 9 & 5.96 \\
\hline & Solo Parent & 1 & 0.66 \\
\hline \multirow[t]{5}{*}{ Years in Service } & Widow/Widower & 4 & 2.65 \\
\hline & 11 - 15 years & 89 & 58.9 \\
\hline & $16-20$ years & 8 & 5.3 \\
\hline & 21 - 30 years & 8 & 5.3 \\
\hline & 31 above & 46 & 30.5 \\
\hline \multirow{4}{*}{$\begin{array}{l}\text { Educational } \\
\text { Attainment }\end{array}$} & UNIT EARNER (MS/MA) & 47 & 31.13 \\
\hline & MASTER'S GRADUATE & 46 & 30.46 \\
\hline & $\begin{array}{l}\text { UNIT EARNER } \\
\text { (PhD/Ed.D) }\end{array}$ & 35 & 23.18 \\
\hline & DOCTORAL GRADUATE & 23 & 15.23 \\
\hline \multirow[t]{15}{*}{ Academic Rank } & Professor 5 & 1 & 0.66 \\
\hline & Professor 3 & 1 & 0.66 \\
\hline & Professor 2 & 1 & 0.66 \\
\hline & Assoc. Professor 5 & 6 & 3.97 \\
\hline & Assoc. Professor 4 & 2 & 1.32 \\
\hline & Assoc. Professor 3 & 1 & 0.66 \\
\hline & Assoc. Professor 2 & 8 & 5.30 \\
\hline & Assoc. Professor 1 & 2 & 1.32 \\
\hline & Asst. Professor 4 & 3 & 1.99 \\
\hline & Asst. Professor 3 & 4 & 2.65 \\
\hline & Asst. Professor 2 & 8 & 5.30 \\
\hline & Asst. Professor 1 & 9 & 5.96 \\
\hline & Instructor 3 & 21 & 13.91 \\
\hline & Instructor 2 & 17 & 11.26 \\
\hline & Instructor 1 & 67 & 44.37 \\
\hline
\end{tabular}

Table 1 shows that the majority of the respondents were female faculty with 53.64 percent with the frequency of 81 , most of the respondents belonged to the age range of 27.15 percent with the frequency of 41 , in terms of civil status is 47.68 percent with the frequency of 72 were married, majority of the respondents in terms of years in service is 58.9 percent with the frequency of 83 were 11-15 years, in terms of educational attainment most of the respondents were unit earners (MS/MA) is 31.13 percent with the frequency of 47 , and among of the respondents in terms of academic rank were 44.31 percent with the frequency of 67 were instructor 1. 
International Journal of Management, Entrepreneurship, Social Science and Humanities (IJMESH), Vol. 4 (2), 182-192

Integration of Gender and Development Approach on Institutional Programs, Activities, and Projects of

Higher Education Institution: An Input to Strategic Development Plan

Mary Ann S. Hernandez; Marcial M. Bandoy; Lerma P. Buenvinida

Gender equality became the mantra for the suitable and just way of understanding, appreciating, and promoting the roles and rights of women before the so-called male-dominated society that tends to discriminate and isolate women as weaker sex (Stotsky, 2016; United Nations (UN), 2014; Branisa et al., 2013).

The result of distribution somehow can be attributed to several CHED mandates aiming to enhance the quality of higher education in all its mandated functions. The CHED Memorandum Order Number 46 S 2012 indicated all strict requirements to attain the required quality. Implied with the provisions of the memorandum are the stringent rules in the recruitment and selection of new higher education faculty which unlike in the previous rules, anyone desiring to be employed as an instructor should be fully satisfied with all the initial requirements before an appointment for a regular plantilla be finally issued.

This implies that more faculty are married, and the least is solo parents because they have more time for work and taking care of the family. Galvin Alaan Galeon revealed in his study on Correlates of the Health Statuses of the Faculty of Mid-life that the university's faculty midlives are primarily married (82.07 percent). Only 16.04 percent are single, with 1.89 percent of those being widows or widowers. There is not a single one of them who is divorced or has a damaged marriage.

Years of service are commonly used to track an employee's job experience in their field. It refers to the process of determining entitlement, entrusting, and benefit amounts for employee participants in taxqualified pension plans by measuring service. To qualify for benefits, it is frequently required that years of service be completed without interruption.

In a study on Correlates of the Health Statuses of the Faculty of Mid-life, Galvin Alaan Galeon stated that the faculty midlives of this research served the institution for 4 to 37 years. The research participants' year of service is 18.23 years on average, with a standard deviation of 8.27, indicating that their years of teaching are widely spread.

Professors' qualifications, experiences, abilities, and competencies have a substantial impact on educational quality. The Commission on Higher Education (CHED) requires that teachers at higher education levels have at least a master's degree in the fields of specialization in that they teach to assess the faculty's crucial role in influencing educational outcomes. The Faculty Development Program (FDP) is a vital issue in manifesting the foundation for a substantial great educational system. According to CHED Memorandum No. 03 series of 2016, contributes to the quality of education in HEIs by providing scholarships to students who do not have a master's or doctoral degree, if their current degree is not aligned with their specialization, or if they want to pursue a second degree in an emerging discipline that contributes to regional and national development.

To design and prescribe the rules and regulations for implementing the Revised Compensation and Position Classification Plan for faculty positions in SUCs, HEIs, and TEIs using the revised Common Criteria for Faculty Position Evaluation. National Budget Circular No. 461 dated June 1, 1998, the National Compensation Circular (NCC) No. 69 Compensation and Position Classification Plan for Faculty Positions has been revised and upgraded. Furthermore, Civil Service Commission Memorandum Circular No. 17, series of 2013, implements the provisions of the CSC-CHED MOA to harmonize existing CSC and CHED policies on the Qualification Standards (QS) for faculty positions/ranks in State Universities and Colleges and Local Universities and Colleges. 
International Journal of Management, Entrepreneurship, Social Science and Humanities (IJMESH), Vol. 4 (2), 182-192

Integration of Gender and Development Approach on Institutional Programs, Activities, and Projects of

Higher Education Institution: An Input to Strategic Development Plan

Mary Ann S. Hernandez; Marcial M. Bandoy; Lerma P. Buenvinida

Table 2. Summary of Mean Perceptions of Higher Education Institutions' Mandated

Functions

\begin{tabular}{lccc}
\hline Indicative Statement & Mean & SD & Interpretation \\
\hline Instructions & 3.94 & 0.65 & Observed \\
Research & 3.58 & 0.74 & Observed \\
Extension & 3.89 & 0.68 & Observed \\
Management of Resources & 3.73 & 0.73 & Observed \\
Overall Mean & 3.79 & 0.63 & Observed \\
\hline
\end{tabular}

Legend: 1.0-1.49: Not Observed; 1.5-2.49: Slightly Observed; 2.5-3.49: Moderately

Observed; 3.5-4.49: Observed; 4.5-.5.0: Highly Observed

Table 2 presents the results in mainstreaming mandated functions, instructions received the highest mean score of 3.94, extension received the second-highest mean score of 3.89, management of resources received the third-highest mean score of 3.73, and research received the lowest mean score of 3.58. The overall mean score for mainstreaming mandated functions is 3.79 , which interpretation is perceived to be observed.

The Gender and Development (GAD) Center mainstreamed under Republic Act 7192 (an Act Promoting the Integration of Women as Full and Equal Partners of Men in Development and Nation Building and for Other Purposes), as well as the Memorandum Circular from the National Commission on the Role of Filipino Women (NCRFW) with the National Economic Development Authority (NEDA) and the Department of Budget and Management.

For the advancement of RA 7192 and CHED Memorandum Order No. 1 series of 2015, Higher Education Institutions serve as the support organization for the efficient and effective mainstreaming of gender plans, programs, and activities into the areas of instruction, research, extension, and production in the Institute and the local community.

Table 3. Summary of Higher Education Institutions' Mean Level of Integration in GAD-Related Functions

\begin{tabular}{lccc}
\hline Indicative Statement & Mean & SD & Interpretation \\
\hline $\begin{array}{l}\text { Consistency of the output with the VGMO } \\
\begin{array}{l}\text { Impact/contribution to Accreditation } \\
\text { body/ISO/CHED/PCW }\end{array}\end{array}$ & 3.76 & 0.69 & Integrated \\
$\begin{array}{l}\text { Positive Contribution to the main } \\
\text { stakeholders }\end{array}$ & 3.45 & 0.71 & Integrated \\
$\begin{array}{l}\text { Relevance to the Gender and Development } \\
\text { policies }\end{array}$ & 3.66 & 0.77 & Moderately Integrated \\
$\begin{array}{l}\text { Relevance of GAD Initiatives Programs, } \\
\begin{array}{l}\text { Projects, and Activities } \\
\text { Overall Mean }\end{array}\end{array}$ & 3.83 & 0.66 & Integrated \\
\hline
\end{tabular}

Legend: 1.0-1.49: Not Integrated; 1.5-2.49: Slightly Integrated; 2.5-3.49: Moderately Integrated; Integrated; 4.5-.5.0: Highly Integrated

Table 3 presents the results in perceived level of integration of GAD related functions were Relevance of GAD Initiatives Programs, Projects, and Activities obtained the highest mean score of 3.83, which was interpreted as integrated, Consistency of the output with the VGMO obtained a mean score of 3.76, which explained as integrated. Impact/contribution to Accreditation body/ISO/CHED/PCW received a mean score of 3.72, with an integrated interpretation. Relevance to Gender and Development Policies obtained a mean score of 3.66, implying that the analysis was integrated. 
International Journal of Management, Entrepreneurship, Social Science and Humanities (IJMESH), Vol. 4 (2), 182-192

Integration of Gender and Development Approach on Institutional Programs, Activities, and Projects of

Higher Education Institution: An Input to Strategic Development Plan

Mary Ann S. Hernandez; Marcial M. Bandoy; Lerma P. Buenvinida

Gender and Development (GAD) is a development strategy that acknowledges the unequal status and predicament of men and women in society. Faculty members were only moderately aware which managers of educational institutions "very aware," Republic Act 7192, also known as Women in Nation Building, has been applied. All Higher Education Institutions have stated that GAD implementation has been purposeful for them as insufficient training/seminars, a lack of financial assistance and priority for GAD programs have a limited institutional collaboration on GAD-related activities, and their execution is unsustainable (Albaladejo, 2016).

Table 4. Significant Relationship Between Mandated Functions and Integration Level

\begin{tabular}{|c|c|c|}
\hline Functions & $\begin{array}{l}\text { Perceived Level of } \\
\text { Integration }\end{array}$ & Interpretation \\
\hline Instruction & $.727^{* *}$ & High positive correlation \\
\hline Research & $.728^{* *}$ & High positive correlation \\
\hline Extension & $.818^{* *}$ & High positive correlation \\
\hline $\begin{array}{l}\text { Management of } \\
\text { Resources }\end{array}$ & $.872^{* *}$ & High positive correlation \\
\hline $\begin{array}{l}\text { Mainstreaming } \\
\text { Mandated } \\
\text { Functions } \\
\text { (Overall) }\end{array}$ & $.869^{* *}$ & High positive correlation \\
\hline \multicolumn{3}{|c|}{$\begin{array}{l}* * \text {. Correlation is significant at the } 0.01 \text { level (2-tailed). } \\
.90 \text { to } 1.00(-.90 \text { to }-1.00) \text { Very high positive (negative) correlation } \\
.70 \text { to } .89(-.70 \text { to }-.89) \text { High positive (negative) correlation } \\
.50 \text { to } .69(-.50 \text { to }-.69) \text { Moderate positive (negative) correlation } \\
.30 \text { to } .49(-.30 \text { to }-.49) \text { Low positive (negative) correlation } \\
.00 \text { to } .29(.00 \text { to }-.29) \text { Negligible positive (negative) correlation }\end{array}$} \\
\hline
\end{tabular}

Table 4 shows that Pearson Correlation was used to examine the relationship between GAD-aligned PPAs in mainstreaming mandated functions and perceived level of integration of Gender-related functions.

Results indicated that there was a "High positive correlation" between GAD-aligned PPAs in mainstreaming mandated functions such as Instruction $r(149)=.727$, p-value $<.01$, Research $r(149)=.728$, $p$-value $<.01$, Extension $r(149)=.818$, $p$-value $<.01$, management Resources $r(149)=872$, $p$ value $<, 01$, and Overall mainstreaming Mandated Functions $r(149)=.869$, $p$-value $<.01$. This implies that as the Mainstreaming Mandated Functions increase, there is also an increase in the Perceived Level of Integration of GAD Related Functions.

A GAD plan, or gender mainstreaming plan, is a strategy for achieving gender equality. It lays out the framework for agencies, local governments, and community-based organizations (GOCCs) to deal with gender issues that affect them and their clients, as well as their specific commitments. The Department of Budget and Management (DBM), the National Economic and Development Authority (NEDA), and the National Commission on the Role of Filipino Women (NCRFC; now known as the Philippine Commission on Women or PCW) is directed to provide budgetary support to GAD to aid in the implementation of GAD Budget Policy.

The DBM-CHED Joint Circular No. 1 Series of 2016 governs the SUCs levels in the march towards outcomes, ASEAN standards alignment, and typology-based quality assurance alignment. Under the auspices of the Philippine Association of State Universities and Colleges (PASUC), the Department of Budget and Management (DBM) and the Commission on Higher Education (CHED) developed the amended FY 2016 SUC leveling instrument. It aims to classify institutions distinct from Level I to Level $\mathrm{V}$, which Level V is the best regards to institutional performance as measured by four (4) primary 
International Journal of Management, Entrepreneurship, Social Science and Humanities (IJMESH), Vol. 4 (2), $182-192$

Integration of Gender and Development Approach on Institutional Programs, Activities, and Projects of

Higher Education Institution: An Input to Strategic Development Plan

Mary Ann S. Hernandez; Marcial M. Bandoy; Lerma P. Buenvinida

outcomes: instructional quality and relevance, research capability output, community services, and resource management.

Table 5. Gender-related functions and Gender and Development Programs, Activities, and Projects in Mainstreaming Mandated Functions: A Summary Model

\begin{tabular}{cccccc}
\hline Model & Coefficient & B & SE & t & Sig. \\
\hline \multirow{2}{*}{$\mathbf{1}$} & Constant & 0.85 & 0.13 & 6.35 & $<.01$ \\
& Management of Resources & 0.76 & 0.04 & 21.73 & $<.01$ \\
\hline \multirow{2}{*}{$\mathbf{2}$} & Constant & 0.51 & 0.14 & 3.66 & $<.01$ \\
& Management of Resources & 0.53 & 0.05 & 9.73 & $<.01$ \\
& Extension & 0.31 & 0.06 & 5.30 & $<.01$ \\
\hline
\end{tabular}

${ }^{1} F(1,149)=472.237 \quad p<.000 \quad R^{2}=.76$

${ }^{2} F(2,148)=292.940 \quad p<.000 \quad R^{2}=.798$

Table 5 shows, a multiple linear regression was calculated to predict the Perceived Level of Integration on Gender-related functions and Gender and Development Programs, Activities and Projects, and GADaligned PPAs in mainstreaming mandated functions based on Instruction, Research, Extension, and Management of Resources.

For model 1, a significant regression equation for Model 1 was found $[F(1,149)=472.237$, $p$-value $<.01]$, with $\mathrm{R}^{2}$ of 0.76 . Participants predicted Perceived Level of Integration on Gender-related functions and Gender and Development Programs, Activities and Projects is equal to $0.85+0.13$ (Management of Resources).

For model 2, a significant regression equation for Model 2 was found $[F(2,148)=292.94$, p-value $<.01]$, with $\mathrm{R}^{2}$ of 0.798 . Participants predicted Perceived Level of Integration on Gender-related functions and Gender and Development Programs, Activities and Projects is equal to $0.51+0.53$ (Management of Resources) + 0.31 (Extension), where both the Management of Resources and the Extension are coded between 1 and 5 .

The object of measurement increased 0.51 units of Perceived Level of Integration of Gender-related functions and Gender and Development Programs, Activities and Projects for each 0.53 Management of Resources units and 0.31 Extension unit.

For every million increases of pesos allocated for the Gender and Development programs, projects, and activities, there is almost approximately an average of 53 percent translate into a manner by which GAD PPAs integrated to maximize efficiency. Every effort plan and approved by the Board of Regent and launched by the Extension Community Services to the community have an approximately 31 percent probability of Gender and Development is embracing and appreciate that contributes to the development of an institution. These established the framework for the performance of programs, activities, and projects (PAPs) that respect, safeguard, and realize women's rights in the sociocultural, economic, and political realms. GAD dilemma must be in performance commitment contracts, yearly budget proposals, and work and financial plans, according to Executive Order (EO) No. 273 (Approving and Adopting the Philippine Plan for Gender-Responsive Development [PPGD 1995-2025]). The perceived level of integration on gender-related functions as well as Gender and Development Programs, Activities, and Projects was predicted by GAD-aligned PPAs in mainstreaming obligatory functions such as resource management and extension.

Table 6. Moderated Correlation between SUCs and LUCs as a Result

\begin{tabular}{lcccc}
\hline Dependent & $\begin{array}{c}\text { Moderat } \\
\text { or }\end{array}$ & Independent & $\mathrm{R}$ & $\mathrm{p}$-value \\
\hline & & Instruction & 0.0113 & 0.0581 \\
\hline 190 & & & \\
\hline
\end{tabular}


International Journal of Management, Entrepreneurship, Social Science and Humanities (IJMESH), Vol. 4 (2), 182-192

Integration of Gender and Development Approach on Institutional Programs, Activities, and Projects of

Higher Education Institution: An Input to Strategic Development Plan

Mary Ann S. Hernandez; Marcial M. Bandoy; Lerma P. Buenvinida

Perceived Level of Integration on Gender-

related functions and

Gender and

Development Programs,

Activities and Projects

$\begin{array}{cc} & \text { Research } \\ \text { HEI } & \text { Extension } \\ \text { (LUC or } & \text { Management of } \\ \text { SUC) } & \text { Resources }\end{array}$

0.0101

0.0713

0.0001

0.8544

0.0019

Table 6 shows, Process Macro was employed to test if there exists a significant relationship between Perceived Level of Integration on Gender-related functions and Gender and Development Programs, Activities and Projects and GAD-aligned PPAs in mainstreaming mandated functions based on Instruction, Research, Extension, and Management of Resources as moderated by HEI (LUC or SUC).

It revealed that none among the GAD-aligned PPAs in mainstreaming mandated functions based on Instruction ( $\mathrm{r}=.0113$, $\mathrm{p}$-value $>.05)$, Research ( $\mathrm{r}=.0101$, $\mathrm{p}$-value $>.05)$, Extension ( $\mathrm{r}=.001, \mathrm{p}$-value $>.05)$, and Management of Resources ( $r=.0019$, p-value $>.05$ ) shown significance.

The GAD Plan and Budget must be included in the agencies' daily operations and account for at least $5 \%$ of their annual budgets. GAD-related activities, as well as those that help poverty reduction, economic development, especially for marginalized women, protection, promotion, and the fulfillment of women's human rights, and gender-responsive governance, are considered sufficient compliance with the criteria.

All agencies must follow existing national procedures for mainstreaming a gender perspective in agency and local plans to adapt to more sustainable performance-based planning and budgeting. On the Board Resolution No. 1, s. 2010, the Philippine Commission on Women (PCW), formerly known as the National Commission on the Role of Filipino Women (NCRFW), authorized and adopted the Republic Act No. 9710, also known as the Women's Magna Carta, Implementing Rules and Regulations (MCW).To promote and achieve women's human rights and eliminate gender discrimination in systems, structures, policies, programs, processes, and procedures; gender mainstreaming should be promoted as a policy in SUCs, GOCCs, and LGUs are agencies, offices, bureaucracies, and instrumentalities of the government At least 5\% of total agency or local government budget appropriations must be spent on GAD projects and programs. The agency GAD budget includes resources to promote gender perspectives in regular/flagship programs and projects and, in addition, a counterpart fund to support ODA-funded gender-responsive projects.

\section{CONCLUSION AND RECOMMENDATION}

Based on the findings indicated, there was a "High positive correlation" between GAD-aligned PPAs in mainstreaming mandated functions such as Instruction, Research, Extension, management Resources, and Overall Mainstreaming Mandated Functions. The object of measurement increased of Perceived Level of Integration of Gender-related functions and Gender and Development Programs, Activities and Projects for each Management of Resources units and Extension unit. It also revealed that none among the GAD-aligned PPAs in mainstreaming mandated functions based on Instruction, Research, Extension, and Management of Resources showed significance.

It is suggested that based on the findings, the Higher Education Institutions (HEIs) shall need to include the implementation of standard requirements in the recruitment of the faculty that they earn units in the postgraduate degree that develop strong identities and character as professionals as governing by access to quality professional development and standard of quality education. The school administrators, faculty members, and employees shall highly observe to coordinate with all the units/person concern in the formulation and implementation in gender mainstreaming of GAD in their policies, people, programs, projects, activities (PPAs), and enabling mechanisms as entry points to make the agencies gender-responsive in instruction, research, extension, and management of 
International Journal of Management, Entrepreneurship, Social Science and Humanities (IJMESH), Vol. 4 (2), 182-192

Integration of Gender and Development Approach on Institutional Programs, Activities, and Projects of

Higher Education Institution: An Input to Strategic Development Plan

Mary Ann S. Hernandez; Marcial M. Bandoy; Lerma P. Buenvinida

resources. At least five percent (5\%) allotted to any or all of the overall agency budget appropriations that match the agency GAD Plan and Budget of GAD funds to support GAD-aligned programs, projects, and activities by the agency or institution. In consideration of the research function, there is a need to identify and develop an interest in a quality research topic that will further solicit information and intensify studies on individual sex roles and gender differences. It is suggested to conduct monitoring and evaluation in the integration and implementation of GAD-aligned PPAs to collate a wide variety of best practices and produce a substantial journal.

\section{REFERENCES}

[1] Mary Rose M. Salagubang, and Franz Jude S. Abelgasc. Women and Gender in Development: An Analysis of Gender and Development (GAD) Programs and Fund Utilization of Quezon and Pasig Cities.; Batangas Eastern College.; Luz y Saber Vol. 14 No. 1 \& 2 (December 2020)

[2] Janet G. Stotsky. Gender Budgeting: Fiscal Context and Current Outcomes. (C) 2016 International Monetary Fund. Authorized for distribution by Prakash Loungani and Catherine Pattillo July 2016. JEL Classification Numbers: H00, I3, J16., Author's E-Mail Address: jstotsky@imf.org

[3] Boris Branisa, Stephan Klasen, and Maria Ziegler. Gender Inequality in Social Institutions and Gendered Development Outcomes., May 2013. World Development 45:252-268 DOI:10.1016/j.worlddev.2012.12.003

[4] CHED Memorandum Order No. 46 Series of 2012, Policy-Standard to Enhance Quality Assurance (QA) in Philippine Higher Education Through an Outcomes-Based and Typology-Based QA.

[5] Galvin Alaan Galeon, Correlates of the Faculty's Health Statuses in Midlife. DOI: 10.4103/09767800.179168. J Midlife Health. 2016 Jan-Mar; 7(1): 15-21.

[6] Commission on Higher Education Memorandum Order No. 03, Series of 2016. Guidelines on Graduate Education Scholarship for Faculty and Staff Development in the K to 12 Transition Period

[7] Department and Budget Management - National Budget Circular No. 461 of June 1, 19198., Revising and Upgrading the National Compensation Circular (NCC) No. 69 Compensation and Position Classification Plan for Faculty Positions

[8] CHED Memorandum Order No. 1 Series of 2015, Establishing the Policies and Guidelines on Gender and Development in the Commission on Higher Education and Higher Education Institutions (HEIs)

[9] Women in Development and Nation Building Act: An Act Promoting the Integration of Women as Full and Equal Partners of Men in Development and Nation Building and for Other Purposes (Republic Act 7192).

[10] Albaladejo, Elmer M. Implementation of Gender and Development among Higher Education Institutions: Input to GAD Enhancement Program JPAIR Institutional Research 7(1), June 2016, DOI:10.7719/irj.v7i1.368

[11] Joint Circular No. 1 Series of 2016 from the Department of Budget and Management (DBM) and the Commission on Higher Education (CHED): FY 2016 Levelling Instruments for SUCs and Implementation Guidelines

[12] An Act Providing for the Magna Carta of Women: Implementing Rules and Regulations, Republic Act No. 9710. 